\title{
Molecular detection of Trypanosoma sp. and Blastocrithidia sp. (Trypanosomatidae) in phlebotomine sand flies (Psychodidae) in the Federal District of Brazil
}

\author{
Tauana de Sousa Ferreira ${ }^{[1]}$, Thaís Tâmara Castro Minuzzi-Souza ${ }^{[1]}$, \\ Andrey José de Andrade ${ }^{[1]}$, Thais Oliveira Coelho[1], Douglas de Almeida Rocha ${ }^{[1]}$, \\ Marcos Takashi Obara ${ }^{[2]}$, Mariana Hecht ${ }^{[3]}$, Nadjar Nitz ${ }^{[3]}$ and Rodrigo Gurgel-Gonçalves ${ }^{[1]}$
}

[1]. Laboratório de Parasitologia Médica e Biologia de Vetores, Faculdade de Medicina, Universidade de Brasília, Brasília, Distrito Federal, Brasil. [2]. Faculdade de Ceilândia, Universidade de Brasília, Ceilândia, Distrito Federal, Brasil. [3]. Laboratório Interdisciplinar de Biociências, Faculdade de Medicina, Universidade de Brasília, Brasília, Distrito Federal, Brasil.

\begin{abstract}
Introduction: This study describes the occurrence of trypanosomatids in phlebotomines in Brasília, Brazil. Methods: Two hundred and ten females of 13 sand fly species were analyzed by polymerase chain reaction (PCR) using different molecular markers (D7 24S $\alpha$ rRNA, kDNA, and ITS1) and sequencing. Results: PCR revealed trypanosomatid-positive samples from Nyssomyia whitmani and Evandromyia evandroi, which were negative by kDNA and ITS1 Leishmania-specific PCRs. DNA sequence analysis of D7 24S $\alpha$ rRNA amplicons indicated the occurrence of Blastocrithidia sp. and Trypanosoma sp. in Nyssomyia whitmani and Evandromyia evandroi, respectively. Conclusions: Two trypanosomatid species other than Leishmania sp. were found to circulate in sand flies in Central Brazil.
\end{abstract}

Keywords: PCR. Trypanosomatids. Phlebotominae.

Phlebotomine sand flies (Diptera: Psychodidae) are vectors of Leishmania spp., which infect people living in poverty worldwide. Furthermore, sand flies are also known to transmit other microorganisms such as trypanosomatid protozoa (Herpetomonas, Blastocrithidia, Trypanosoma, and Endotrypanum), bacteria (Bartonella), and arboviruses

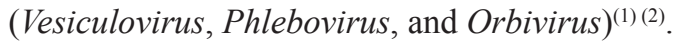

In the New World, 58 species of Phlebotominae are proven or suspected vectors for the transmission of Leishmania species to man and other animals ${ }^{(3)}$. However, the occurrence of trypanosomatids in sand fly species and domestic and wild mammals has yet to be fully investigated in the Cerrado biome, particularly in the Federal District (FD) of Brazil ${ }^{(4)}$, where autochthonous human cases of visceral and cutaneous leishmaniasis have been recorded ${ }^{(5)(6)}$. The present study focused on the search for Leishmania and other trypanosomatids in sand flies from two localities of FD.

Corresponding auhor: Dr. Rodrigo Gurgel-Gonçalves. Laboratório de Parasitologia Médica e Biologia de Vetores/Área Patologia/FM/UnB. Caixa Postal: 4569, Campus Universitário Darcy Ribeiro, Asa Norte, 70904-970 Brasília, Distrito Federal, Brasil.

Phone: 5561 3107-1787

e-mail: rgurgel@unb.br

Received 8 March 2015

Accepted 11 May 2015
Specimens were captured in two areas: 1) a gallery forest located at the Água Limpa Farm owned by the University of Brasília (155' $\left.41.00^{\prime \prime} \mathrm{S} ; 4^{\circ} 56^{\prime} 38.88^{\prime \prime} \mathrm{W}\right)$; and 2) a domiciliary unit located in the Boa Vista neighborhood within the administrative region of Fercal $\left(15^{\circ} 37^{\prime} 28.6^{\prime \prime} \mathrm{S} ; 7^{\circ} 52^{\prime} 23.0^{\prime \prime} \mathrm{W}\right)$. At the Água Limpa Farm, the sampling was performed during November, 2013 using light traps: five $\mathrm{HP}^{\mathrm{TM}}$ and two Shannon. The domiciliary unit was sampled during April, 2014 using two Shannon traps and $10 \mathrm{HP}^{\mathrm{TM}}$ traps. The Shannon traps were installed in the forest remnant close to the house and the $\mathrm{HP}^{\mathrm{TM}}$ traps were installed in animal shelters on the periphery of the house.

The collected female flies were dissected to separate the head and the spermathecae; both were cleared and mounted in Canada balsam for species identification ${ }^{(7)}$. Other body parts (thorax, part of the abdomen, legs, and wings) were placed in an Eppendorf tube $(1.5 \mathrm{~mL})$ and assigned a code number. A variable number of female specimens (one to ten), belonging to the same species and capture sites, were pooled for total deoxyribonucleic acid (DNA) extraction using the Illustra tissue and cells genomicPrep Mini Spin Kit, according to the manufacturer's instructions (GE Healthcare, New York, USA). Deoxyribonucleic acid integrity of the samples was checked by a PCR designed to amplify the cacophony gene IVS6 region in sand flies with specific primers (5Llcac 5'-GTG GCC GAA CAT AAT GTT AG-3' and 3Llcac5'-CCA CGAACA AGT TCA ACA TC- $\left.3^{\prime}\right)^{(8)}$, under the following conditions: $95^{\circ} \mathrm{C}$ for $5 \mathrm{~min}$, 35 cycles of $95^{\circ} \mathrm{C}$ for $30 \mathrm{~s}, 57^{\circ} \mathrm{C}$ for $30 \mathrm{~s}$, and $72^{\circ} \mathrm{C}$ for $30 \mathrm{~s}$ with a final extension at $72^{\circ} \mathrm{C}$ for $10 \mathrm{~min}$. 
Tripanosomatid detection was performed by amplifying the polymorphic region of the $\mathrm{D} 7$ domain of the $24 \mathrm{~S} \alpha$ ribosomal ribonucleic acid (rRNA) gene (primers: D75 5'-GCA GAT CTT GGT TGG CGT AG-3' and D76 5'-GGT TCT CTG TTG CCC CTT TT-3') that corresponds to conserved sequences of approximately $225 \mathrm{bp}$ found in trypanosome and Leishmania spp. genomes ${ }^{(9)}$. Polymerase chain reaction was performed in a $25 \mu \mathrm{L}$ volume containing $10 \mathrm{ng} / \mu \mathrm{L}$ DNA, $1.0 \mu \mathrm{M} \mathrm{MgCl}_{2}$, $0.2 \mu \mathrm{M}$ dNTPs, $0.1 \mu \mathrm{M}$ of each primer, and $1.5 \mathrm{U}$ Platinum Taq DNA polymerase (Invitrogen, Life Technologies, Brazil). The amplification conditions were as described by Schijman et al. ${ }^{(10)}$. The positive controls used in the PCR reactions were obtained from cultures of Trypanosoma cruzi (Berenice strain), Trypanosoma rangeli (SC-58 strain), and Leishmania (Leishmania) infantum (MCER/BR/1979/M6445). Milli-Q water was used as a negative control. All reactions were performed in a thermocycler (MyCycler, Bio-Rad, California, USA). Polymerase chain reaction products were analyzed by electrophoresis on $2 \%$ agarose gels.

To confirm the positive Leishmania sp. results, samples with positive D75/D76 primer amplifications were retested with kinetoplast deoxyribonucleic acid (kDNA)-PCR (120bp) and internal transcribed spacer 1 (ITS1)-PCR (308-338bp), which are specific for Leishmania. For kDNA (primers FW 5'-GGG GAG GGG CGT TCT GCG AA-3', BW-B 5-CCG CCC CTA TTT TAC ACC AAC CCC-3, and BW-CA 5'-GGC CCA CTA TAT TAC ACC AAC CCC-3'), PCR was performed with a final volume of $25 \mu \mathrm{L}$, and with $10 \mathrm{ng}$ DNA under the following conditions: $0.2 \mu \mathrm{M}$ dNTPs, $2.0 \mu \mathrm{M} \mathrm{MgCl}_{2}, 0.24 \mu \mathrm{M}$ each primer; and $1.5 \mathrm{U}$ Platinum Taq DNA polymerase. The PCR cycling conditions were $95^{\circ} \mathrm{C}$ for $5 \mathrm{~min}$, followed by 40 cycles of $95^{\circ} \mathrm{C}$ for $30 \mathrm{~s}, 66^{\circ} \mathrm{C}$ for $30 \mathrm{~s}$, and $72^{\circ} \mathrm{C}$ for $30 \mathrm{~s}$, with a final extension of $72^{\circ} \mathrm{C}$ for 5 min. Positive controls consisted of DNA from cultures of $L$. (L.) infantum (MCER/BR/1979/M6445), Leishmania (Leishmania) amazonensis (IFLA/BR/1967/PH8), and Leishmania (Viannia) braziliensis (MHOM/BR/1975/M2904).

Internal transcribed spacer 1-PCR was performed using primers LITS1 5'-CTG GAT TTT GCC CAT ATG-3' and L5.85 5' ${ }^{\prime}$-TCG TGA TAC CAC TTA CAC TT- ${ }^{\prime}$ as described by Tojal da Silva et al. ${ }^{(11)}$. The reactions were prepared in a final volume of $25 \mu \mathrm{L}$ containing $10 \mathrm{ng} / \mu \mathrm{L}$ DNA, $2.0 \mu \mathrm{M} \mathrm{MgCl}_{2}$, $0.2 \mu \mathrm{M}$ dNTPs, $0.1 \mu \mathrm{M}$ each primer, and $1.5 \mathrm{U}$ Platinum Taq DNA polymerase, under the following conditions: $95^{\circ} \mathrm{C}$ for 5 min, 35 cycles at $95^{\circ} \mathrm{C}$ for $30 \mathrm{~s}, 58^{\circ} \mathrm{C}$ for $30 \mathrm{~s}$, and $72^{\circ} \mathrm{C}$ for $30 \mathrm{~s}$ with a final extension step at $72^{\circ} \mathrm{C}$ for $5 \mathrm{~min}$. To increase the sensitivity of the reaction, PCR products were re-amplified with the same primers and the same conditions. All reactions were performed in a MyCycler thermocycler. Positive and negative controls used in ITS-1 PCR were the same as those used in the kDNA PCR. Amplicons were separated on 1.3\% agarose gels.

Amplified fragments were purified using an Illustra GFX PCR DNA\& Gel Band Purification Kit (GE Healthcare) and sequenced for identification of trypanosomatids by a commercial provider (Genomic Engenharia Molecular, São Paulo, Brazil). Sequences obtained were edited using Geneious software (Biomatters, New Zealand) and compared with sequences deposited at GenBank using the Basic Local Alignment Search Tool, nucleotides (BLASTn) algorithm at the National Center for Biotechnology Information, USA (http://www.ncbi.nlm.nih.gov/BLAST).

A total of 216 female sand flies were captured. At the Água Limpa Farm, specimens from three species were obtained: Psathyromyia bigeniculata $(\mathrm{n}=8)$; Pintomyia pessoai $(\mathrm{n}=7)$; and Pintomyia monticola $(\mathrm{n}=3)$. At the domiciliary unit of Fercal, 11 species were identified: Nyssomyia whitmani $(\mathrm{n}=141)$; Evandromyia lenti $(\mathrm{n}=30)$; Psychodopygus davisi $(\mathrm{n}=10)$; Evandromyia evandroi $(\mathrm{n}=8)$; Micropygomyia acanthopharynx $(\mathrm{n}=3)$; Lutzomyia longipalpis $(\mathrm{n}=1)$; Evandromyia termitophila $(\mathrm{n}=1)$; Pintomyia misionensis $(\mathrm{n}=1)$; Psathyromyia bigeniculata $(\mathrm{n}=1)$; Psathyromyia lutziana $(\mathrm{n}=1)$; and Pressatia sp. $(\mathrm{n}=1)$.

Deoxyribonucleic acid was successfully extracted from 210 females which had been pooled into 24 samples. Fragments that corresponded to the cacophony gene were amplified in all of the samples, demonstrating the integrity of the extracted DNA. Subsequent PCR analyses revealed that three of these samples obtained from the peridomiciliary environment of the domestic unit of Fercal were positive for trypanosomatids (225bp bands). Two were from Ny. whitmani and one was from Ev. evandroi. All samples above tested negative for Leishmania spp. by the kDNA and ITS1 PCRs. DNA sequence analyses of two D7 24S $\alpha$ rRNA amplicons indicated the presence of Blastocrithidia sp. in $\mathrm{Ny}$. whitmani and Trypanosoma sp. in Ev. evandroi (Table 1).The respective sequences have been deposited in GenBank (accession numbers KR149124 and KR149125). Assuming that only one insect per pool was positive the minimum infection rate was calculated as $1.4 \%$ for $N y$. whitmani and $12.5 \%$ for Ev. evandroi.

To our knowledge, this represents the first registration of the presence of trypanosomatid DNA of the genus Blastocrithidia in $N y$. whitmani. Although sand flies most commonly serve as hosts for Leishmania species, the occurrence of Trypanosoma, Endotrypanum, Crithidia, Blastocrithidia, Herpetomonas, and Leptomonas have also been reported ${ }^{(1)(2)}$. For example, Rocha

TABLE 1 - Genera of Trypanosomatids identified in phlebotomine sand fly species in a domestic unit (peridomicile) of the administrative region of Fercal, Federal District, Brazil.

\begin{tabular}{lcccc}
\hline Species & PCR & Blastn* & Accession number & \multicolumn{1}{c}{ Identity** } \\
\hline Evandromyia evandroi & 24S $\alpha$ rRNA & Trypanosoma sp. & dbj|AB447493.1 & $223 / 261(85.4 \%)$ \\
Nyssomyia whitmani & 24S $\alpha$ rRNA & Blastocrithidia sp. & gb|AY820897.1 & $236 / 250(94.4 \%)$ \\
\hline
\end{tabular}

PCR: polymerase chain reaction; rRNA: ribosomal ribonucleic acid.*Basic Local Alignment Search Tool. **Number of bases that match the database sequence. 
et al. ${ }^{(2)}$ showed that $21 \%$ of Pintomyia fischeri sand fly samples were positive for Herpetomonas samuelpessoai.

The current study presents molecular evidence that confirms the association between Trypanosoma sp. and Evandromyia evandroi. Previously, Shaw et al. ${ }^{(1)}$ reported the presence of Trypanosoma sp. in Evandromyia infraspinosa, Evandromyia saulensis, Evandromyia pinottii, Evandromyia evandroi, Nyssomyia antunesi, Nyssomyia whitmani, Micropygomyia micropyga, Micropygomyia rorotaensis, Micropygomyia trinidadensis, Sciopemyia sordellii, and Psychodopygus davisi. However, these findings should be evaluated with caution, as most were based on morphological characteristics, which are not sufficient to distinguish among trypanosomatids.

The Ev. evandroi sample analyzed in the current study presented $85 \%$ identity with a Trypanosoma cf. varani snake isolate, described by Sato et al. ${ }^{(12)}$. The first evidence of the transmission of snake trypanosomes by sand flies was described by Viola et al. ${ }^{(13)}$, who identified trypanosomes from Viannamyia tuberculata that had approximately $94 \%$ similarity to a trypanosome isolated from Crotalus durissus. Furthermore, some sand flies have been infected by Trypanosoma species acquired from amphibians ${ }^{(14)}$. However, the identification of the trypanosomes in this study requires further confirmation, because sequence analysis showed identity values $<90 \%$. Future studies using additional species-specific molecular markers might be able to determine definitively which Trypanosoma species are associated with Ev. evandroi in Central Brazil.

The sequence obtained from $N y$. whitmani presented $94 \%$ identity with Blastocrithidia sp. sequences. Rocha et al. ${ }^{(2)}$ also detected Blastocrithidia in Pi. fischeri using molecular methods. The mechanism of transmission of these monoxenous trypanosomatids might be through ingestion of the protozoa present in insect feces ${ }^{(15)}$.

Our results increase the knowledge of the spectrum of protozoa infecting phlebotomines in Brazil. It can be concluded that two trypanosomatid species other than Leishmania sp. circulate in sand flies and, more specifically, in the species $N y$. whitmani and Ev. evandroi within peridomiciles in the FD. Because only minimal potential infection rates were determined, the data suggest that the occurrence of Blastocrithidia sp. and Trypanosoma sp. in sand flies in peridomiciliary environments might be more frequent than currently understood. Therefore, epidemiological studies of Leishmania based solely on the detection of flagellates in fresh samples of sand fly species should be evaluated with caution.

\section{ACKNOWLEDGMENTS}

The authors would like to thank Mr. Divino Eterno dos Santos for allowing the sampling to take place on his property. We also thank Vagner José Mendonça and Cesar Augusto Cuba Cuba for reviewing the manuscript. This research was partially funded by Coordination for the Improvement of Higher Education Personnel [Coordenação de Aperfeiçoamento de Pessoal de Nivel Superior (CAPES)]/Brazilian Ministry of Education.

\section{CONFLICT OF INTEREST}

The authors declare that there is no conflict of interest.

\section{FINANCIAL SUPPORT}

Funding for this research was provided by Coordination for the Improvement of Higher Education Personnel (CAPES) and National Council for Scientific and Technological Development (CNPq).

\section{REFERENCES}

1. Shaw J, Rosa AT, Souza A, Cruz AC. Transmissão de outros agentes. In Rangel EF, Lainson R (orgs). Flebotomíneos do Brasil. Rio de Janeiro: FIOCRUZ; 2003. p. 337-351.

2. Rocha LS, dos Santos CB, Falqueto A, Grimaldi Jr G, Cupolillo E. Molecular biological identification of monoxenous trypanosomatids and Leishmania from antropophilic sand flies (Diptera: Psychodidae) in Southeast Brazil. Parasitol Res 2010; 107:465-468.

3. Maroli M, Feliciangeli MD, Bichaud L, Charrel RN, Gradoni L. Phlebotomine sandflies and the spreading of leishmaniases and other diseases of public health concern. Med Vet Entomol 2013; 27:123-147.

4. Cardoso RM, Araújo NN, Romero GA, Souza TT, Dietrich AG, Mendes JD, et al. Expanding the knowledge about Leishmania species in wild mammals and dogs in the Brazilian savannah. Parasit Vectors 2015; 8:171.

5. Sampaio RNR, Gonçalves MC, Leite VA, França BV, Santos G, Carvalho MSL, et al. Study on the transmission of American cutaneous leishmaniasis in the Federal District. Rev Soc Bras Med Trop 2009; 42:686-690.

6. Carranza-Tamayo CO, Carvalho MSL, Bredt A, Bofil MIR, Rodrigues RMB, Silva AD, et al. Autochthonous visceral leishmaniasis in Brasília, Federal District, Brazil. Rev Soc Bras Med Trop 2010; 43:396-399.

7. Galati EAB. Morfologia e terminologia de adultos e identificação dos táxons da América. In: Rangel EF, Lainson R, orgs. Flebotomíneos do Brasil. Rio de Janeiro: FIOCRUZ; 2003. p. 53-175.

8. Lins RM, Oliveira SG, Souza NA, de Queiroz RG, Justiniano SC, Ward RD, et al. Molecular evolution of the cacophony IVS6 region in sandflies. Insect Mol Biol 2002; 11:117-122.

9. Souto RP, Zingales B. Sensitive detection and strain classification of Trypanosoma cruzi by amplification of a ribosomal RNA sequence. Mol Biochem Parasitol 1993; 62:45.

10. Schijman AG, Lauricella MA, Marcet PL, Duffy T, Cardinal MV, Bisio M, et al. Differential detection of Blastocrithidia triatomae and Trypanosoma cruzi by amplification of $24 \mathrm{~s}$ alpha ribosomal RNA genes in faeces of sylvatic triatomine species from rural northwestern Argentina. Acta Trop 2006; 99:50-54.

11. Tojal da Silva AC, Cupolillo E, Volpini AC, Almeida R, Romero GA. Species diversity causing human cutaneous leishmaniasis in Rio Branco, State of Acre, Brazil. Trop Med Int Health 2006; 11:1388-1398.

12. Sato H, Takano A, Kawabata H, Une Y, Watanabe H, Mukhtar MM. Trypanosoma cf. varani in an imported ball python (Python reginus) from Ghana. J Parasitol 2009; 95:1029-1033. 
13. Viola LB, Campaner M, Takata CS, Ferreira RC, Rodrigues AC, Freitas RA, et al. Phylogeny of snake trypanosomes inferred by SSU rDNA sequences, their possible transmission by phlebotomines, and taxonomic appraisal by molecular, crossinfection and morphological analysis. Parasitol 2008; 135:595-605.

14. Ferreira RC, De Souza AA, Freitas RA, Campaner M, Takata $\mathrm{CS}$, Barrett TV, et al. A phylogenetic lineage of closely related trypanosomes (Trypanosomatidae, Kinetoplastida) of anurans and sand flies (Psychodidae, Diptera) sharing the same ecotopes in brazilian amazonia. J Eukaryot Microbiol 2008; 55:427-435.

15. Wallace FG. The trypanosomatid parasites of insects and arachnids. Exp Parasitol 1966; 18:124-193. 